\title{
ANALYSIS OF EFFECT SIZE COMPANY, PROFITABILITY, AND LEVERAGE AGAINST SOCIAL RESPONSIBILITY DISCLOSURE OF LISTED MINING INDUSTRY IN INDONESIA STOCK EXCHANGE PERIOD 2009-2012
}

\author{
Haninun \\ Nurdiawansyah \\ (Universitas Bandar Lampung) \\ Email: haninun@ubl.ac.id \\ Email:nurdiawansyah.iwan@yahoo.com
}

\begin{abstract}
This study aims to identify and analyze the effect of firm size, profitability and leverage on the disclosure of social responsibility in the mining industry sectors listed on the Indonesia Stock Exchange 2009-2012. The hypothesis was first put forward in a positive effect of firm size on corporate social responsibility disclosure, the second hypothesis is the positive effect on the profitability of social responsibility disclosure, the third hypothesis is the negative effect of leverage on corporate social responsibility disclosure. Measurement of corporate social responsibility is based on the category of the Global Reporting Index (GRI) is seen in the company's annual financial statements.

The sample in this study is that the mining industry is listed in Indonesia Stock Exchange 2009-2012. Sampling using purposive sampling in order to obtain a total sample of 16 mining companies that meet the criteria of the study sample set. Company size is measured by total assets, profitability measured by Return on Assets ( ROA ), and leverage is measured using a Debt Equity Ratio ( DER ). The technique of data analysis done with the classical assumption, hypothesis testing using multiple linear regression analysis using SPSS 18.0 for windows.

The results showed that in partial firm size, profitability has positive influence on social responsibility disclosure in the mining industry are listed in the Indonesia Stock Exchange, while the variable leverage negatively affects social responsibility disclosure in the mining industry are listed in the Indonesia Stock Exchange.
\end{abstract}

Keywords: Company Size, Profitability, Leverage, Corporate Social Responsibility (CSR).

\section{Latar Belakang}

Informasi merupakan kebutuhan yang mendasar bagi para investor dan calon investor untuk pengambilan keputusan. Adanya informasi yang lengkap, akurat serta tepat waktu memungkinkan investor untuk melakukan pengambilan keputusan secara rasional sehingga hasil yang dicapai sesuai dengan yang diharapkan. Penyediaan informasi yang luas dalam laporan keuangan merupakan suatu keharusan yang disebabkan karena adanya permintaan berbagai pihak dengan informasi tersebut. Akuntansi sebagai alat pertanggungjawaban 
mempunyai fungsi sebagai alat kendali terhadap aktivitas suatu unit usaha (Zuhroh dan Sukmawati, 2003).

Pelaksanaan CSR yang menuntut adanya pertanggungjawaban dari perusahaan kepada masyarakat (sosial) dan lingkungan melanda dunia bisnis secara global, tidak terkecuali di Indonesia. Dengan diberlakukannya beberapa peraturan dan perundangan seperti UndangUndang Nomor 40 tahun 2007 tentang Perseroan Terbatas (UUPT) dalam pasal 74 ayat 1 yang menyatakan bahwa PT yang menjalankan usaha di bidang dan/atau bersangkutan dengan sumber daya alam wajib menjalankan tanggung jawab sosial dan lingkungan.

Beberapa penelitian yang terkait dengan pengungkapan tanggung jawab sosial perusahaan menunjukkan keanekaragaman hasil. Sembiring (2005), Lucyanda dan Siagian (2012) menemukan pengaruh yang signifikan ukuran perusahaan (firm size) terhadap pengungkapan tanggung jawab sosial perusahaan. Namun, hal ini tidak sejalan dengan hasil penelitian yang dilakukan oleh Anggraini (2006), Sitepu dan Siregar (2007) yang menyatakan bahwa ukuran perusahaantidak berpengaruh terhadap pengungkapan tanggung jawab sosial perusahaan. Berkaitan dengan profitabilitas, Marbun (2008) dan Lawer (2010) membuktikan adanya pengaruh antara profitabilitas terhadap pengungkapan tanggung jawab sosial perusahaan.

Sembiring (2005) dan Rosmasita (2007) menyatakan profitabilitas tidak berpengaruh terhadap pengungkapan pertanggungjawaban sosial perusahaan. Variabel leverage yang diteliti oleh Marbun (2008) dan Cahya (2010) menunjukkan leverage berpengaruh signifikan terhadap CSRD, sedangkan hasil penelitian Sembiring (2005), Anggraini (2006) dan Lawer (2010) menunjukkan leverage perusahaan tidak memiliki pengaruh yang signifikan. Berdasarkan beberapa penelitian tersebut, maka peeliti ingin meneliti kembali pengaruh ukuran perusahaan, profitabilitas, dan tingkat leverage terhadap pengungkapan tanggung jawab sosial perusahaan (corporate social responsibility).

\section{Rumusan Masalah}

Apakah ukuran perusahaan, tingkat profitabilitas, tingkat leverage perusahaan berpengaruh terhadap pengungkapan tanggung jawab sosial pada sektor industri pertambangan yang terdaftar di Bursa Efek Indonesia? 


\section{Tujuan Penelitian}

Tujuan penelitian ini adalah untuk mendapatkan bukti secara empiris tehadap Pengaruh tingkat ukuran perusahaan, tingkat profitabilitas, tingkat leverage terhadap pengungkapan tanggung jawab sosial.

\section{Telaah Literatur dan Pengembangan Hipotesis}

\subsection{Landasan Teori}

\section{Teori Legitimasi}

Teori legitimasi berfokus pada interaksi antara perusahaan dengan masyarakat. Menurut Dowling dan Pfeffer (1975) dalam Ghozali dan Chariri (2007), hal tersebut didasarkan pada pandangan bahwa perusahaan berusaha untuk menciptakan keselarasan antara nilai-nilai sosial yang melekat dalam kegiatannya dengan norma-norma perilaku yang ada dalam sistem sosial masyarakat dimana perusahaan adalah bagian dari sistem tersebut. Selama kedua sistem nilai tersebut selaras, hal tersebut dapat dipandang sebagai legitimasi perusahaan. Namun, ketika terjadi ketidakselarasan aktual diantara kedua sistem nilai tersebut, maka akan terdapat ancaman terhadap legitimasi perusahaan.

Menurut Ghozali dan Chariri (2007), sebagai dasar dari teori legitimasi adalah adanya kontrak sosial yang terjadi antara perusahaan dan masyarakat dimana perusahaan beroperasi dan menggunakan sumber ekonomi. Selain itu juga dijelaskan bahwa dalam masyarakat yang dinamis, tidak ada sumber kekuatan institusional dan kebutuhan terhadap pelayanan yang bersifat permanen. Oleh karena itu, suatu institusi harus lolos uji legitimasi dan relevansi dengan cara menunjukkan bahwa masyarakat memerlukan jasa perusahaan dan kelompok tertentu yang memperoleh manfaat dari penghargaan yang diterimanya betul-betul mendapat persetujuan masyarakat.

\section{Corporate Social Responsibility(CSR)}

Berbagai definisi mengenai pertanggungjawaban sosial atau CSR telah dikemukakan oleh banyak pihak. Seperti Darwin (2004) dalam Rawi dan Muchlish, (2010) yang mendefinisikan CSR sebagai mekanisme bagi suatu organisasi untuk mengintegrasikan perhatian terhadap lingkungan dan sosial ke dalam operasinya dan interaksinya dengan stakeholder, yang melebihi tanggung jawab organisasi di bidang hukum. 
Menurut Hackston dan Milne, tangggung jawab sosial perusahaan sering disebut juga sebagai corporate social responsibility atau social disclosure, corporate social reporting, social reporting merupakan proses pengkomunikasian dampak sosial dan lingkungan dari kegiatan ekonomi organisasi terhadap kelompok khusus yang berkepentingan dan terhadap masyarakat secara keseluruhan (Sembiring, 2005). Hal tersebut memperluas tanggung jawab organisasi dalam hal ini perusahaan, di luar peran tradisionalnya untuk menyediakan laporan keuangan kepada pemilik modal, khususnya pemegang saham. Perluasan tersebut dibuat dengan asumsi bahwa perusahaan mempunyai tanggung jawab yang lebih luas dibanding hanya mencari laba untuk pemegang saham (Gray et.al, 1995 dalam Hasibuan, 2001).

Dalam penelitian ini, perusahan-perusahaan pertambangan yang diteliti mengacu pada standar GRI (Global Reporting Initiative). GRI adalah sebuah organisasi yang telah mempelopori perkembangan dunia, paling banyak menggunakan kerangka laporan berkelanjutan dan berkomitmen untuk terus-menerus melakukan perbaikan dan penerapan di seluruh dunia.

Konsep pelaporan CSR yang digagas oleh GRI adalah konsep sustainability report yang muncul sebagai akibat adanya konsep sustainability development. Dalam sustainability report digunakan metode triple bottom line, yang tidak hanya melaporan sesuatu yang diukur dari sudut pandang ekonomi saja, melainkan dari sudut pandang ekonomi, sosial dan lingkungan. Gagasan ini merupakan akibat dari adanya 3 dampak operasi perusahaan yaitu ekonomi, sosial dan lingkungan. GRI Guidelines menyebutkan bahwa, perusahaan harus menjelaskan dampak aktivitas perusahaan terhadap ekonomi, lingkungan dan sosial pada bagian standard disclosures. Yang kemudian ketiga dimensi tersebut diperluas menjadi 6 dimensi, yaitu: ekonomi, lingkungan, praktek tenaga kerja, hak asasi manusia, sosial, dan tanggungjawab produk.

\section{Ukuran Perusahaan}

Ukuran perusahaan (size) merupakan skala yang digunakan dalam menentukan besar kecilnya suatu perusahaan berdasarkan indikator tertentu, antara lain total aktiva, log size, nilai saham, jumlah tenaga kerja, penjualan, dan kapitalisasi pasar. Perusahaan yang skalanya besar biasanya cenderung lebih banyak mengungkapkan tanggung jawab sosial daripada perusahaan yang mempunyai skala kecil. 
Pada penelitian ini, ukuran perusahaan dilihat dari total aset yang dimiliki oleh perusahaan. Secara umum perusahaan besar akan mengungkapkan informasi lebih banyak daripada perusahaan kecil.

\section{Profitabilitas}

Rasio profitabilitas mengukur kemampuan para eksekutif perusahaan dalam menciptakan tingkat keuntungan baik dalam bentuk laba perusahaan maupun nilai ekonomis atas penjualan, aset bersih perusahaan maupun modal sendiri (shareholders equity) (Raharjaputra, 2009: 205). Hubungan kinerja keuangan dengan tanggung jawab sosial perusahaan menurut Belkaoui dan Karpik (1989) dalam Pian (2010) paling baik diekspresikan dengan profitabilitas, hal itu disebabkan karena pandangan bahwa tanggapan sosial yang diminta dari manajemen sama dengan kemampuan yang diminta untuk membuat suatu perusahaan memperoleh laba. Selain itu tingkat profitabilitas dapat menunjukkan seberapa baik pengelolaan manajemen perusahaan.

Penelitian ini menggunakan Return on Asset (ROA) sebagai alat ukur profitabilitas perusahaan karena rasio ini dapat mengukur sejauh mana perusahaan menghasilkan laba bersih pada sejumlah aset tertentu, dapat dikatakan pula bahwa ROA merupakan rasio yang menggambarkan kemampuan perusahaan untuk menghasilkan keuntungan dari setiap rupiah aktiva yang digunakan.

\section{Leverage}

Leverage merupakan pengukur besarnya aktiva yang dibiayai dengan hutang yang digunakan untuk membiayai aktiva berasal dari pihak luar (kreditor) dengan kemampuan perusahaan yang digambarkan oleh modal (Harahap, 2007:306). Belkaoui dan Karpik (1989) menyatakan bahwa semakin tinggi tingkat leverage (rasio utang/ekuitas) semakin besar kemungkinan perusahaan akan melanggar perjanjian kredit sehingga perusahaan akan melaporkan laba sekarang lebih tinggi. Perusahaan akan mengurangi biaya-biaya termasuk biaya untuk mengungkapkan informasi sosial.

Rasio leverage keuangan dapat diukur dengan Debt Ratio, Debt to Equity Ratio (DER), Time Interest Earnet Ratio, Fixed Charge Coverage Ratio, dan Debt Service Ratio (Sutrisno, 2003:248-251). Rasio yang digunakan untuk mengukur leverage keuangan dalam penelitian ini adalah Debt to Equity Ratio (DER). DER merupakan proporsi total utang terhadap ekuitas 
pemegang saham. Digunakan DER karena rasio ini menggambarkan keseimbangan antara utang yang dimiliki perusahaan dengan modal sendiri (Sutrisno, 2003:249).

\subsection{Rerangka Pemikiran}

Berdasarkan uraian yang telah dikemukakan sebelumnya, maka digambarkan paradigma penelitian sebagai berikut :

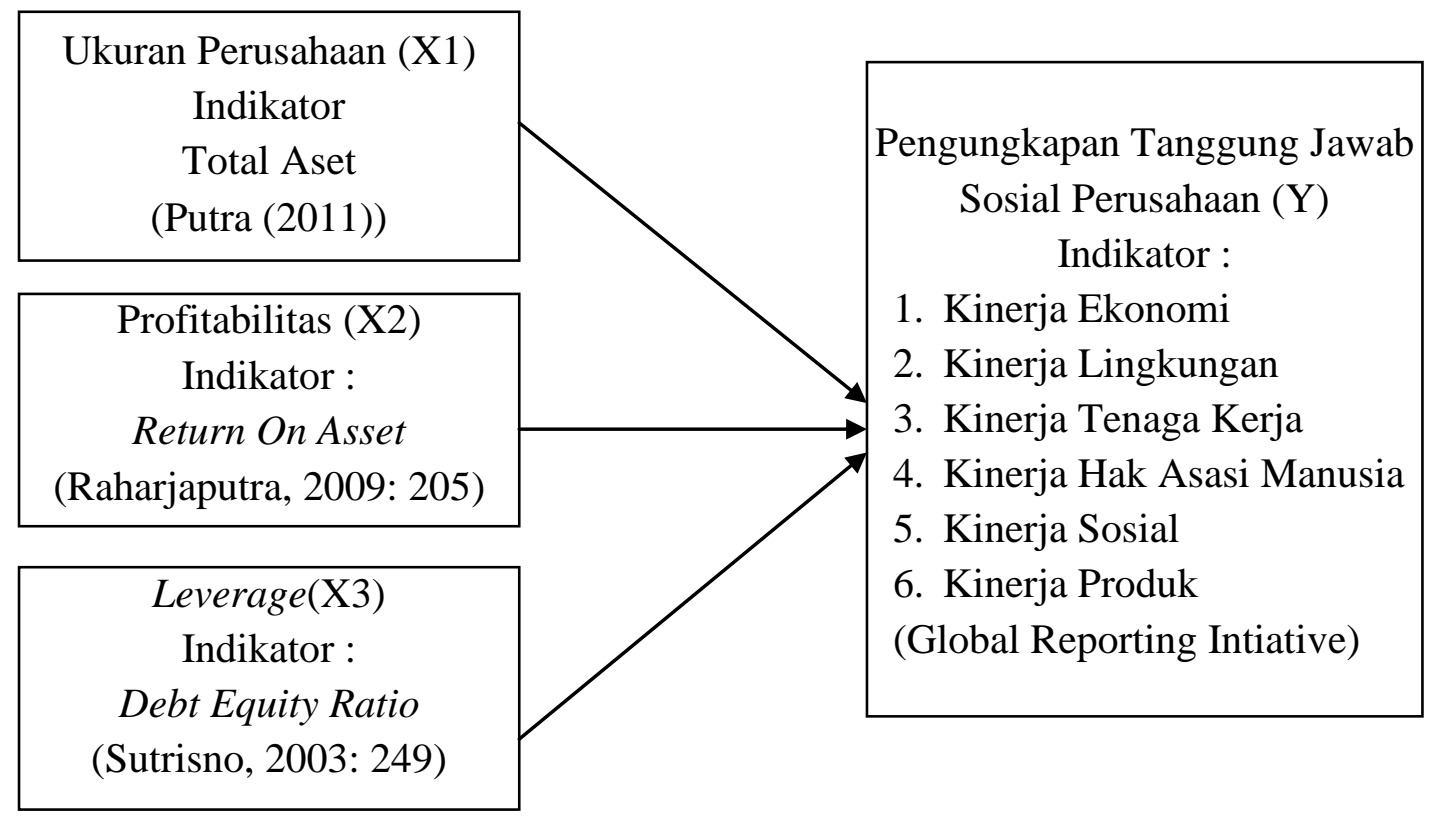

\section{Gambar 1 Rerangka Pemikiran}

\subsection{Hipotesis}

Adapun hipotesis yang diajukan dalam penelitian ini adalah:

1. H1: Ukuranperusahaan berpengaruh secara positif terhadap pengungkapan tanggung jawab sosial perusahaan.

2. H2: Profitabilitas perusahaan berpengaruh secara positif terhadap pengungkapan tanggung jawab sosial perusahaan.

3. H3: Leverage berpengaruh secara negatif terhadap pengungkapan tanggung jawab sosial perusahaan.

\section{Metode Penelitian}

\subsection{Populasi dan Sampel Penelitian}

Populasi penelitian ini adalah seluruh industri pertambangan di Indonesia yang beroperasi periode 2009-2012. Penarikan sampel menggunakan metode purposive sampling, dengan kriteria sebagai berikut: 
a. Perusahaan pertambangan di Indonesia yang terdiri dari Perusahaan Pertambangan yang terdaftar dalam BEI periode 2009-2012.

b. Perusahaan pertambangan yang beroperasi secara kontinyu atau terus menerus selama periode penelitian.

c. Perusahaan pertambangan yang mempublikasikan laporan keuangan secara lengkap selama periode penelitian yaitu tahun periode 2009-2012.

\subsection{Jenis dan Sumber, dan Tehnik Pengumpulan Data}

Penelitian ini menggunakan data sekunder yang berasal dari perusahaan pertambangan yang terdaftar di Bursa Efek Indonesia (www.idx.co.id). Data yang digunakan adalah laporan tahunan perusahaan pertambangan tahun 2009- 2012, dengan tehnik pengumpulan data dokumentasi.

\subsection{Variabel Penelitian, Definisi Operasional dan Pengukuran Variabel}

Variabel dalam penelitian ini terdiri dari satu variabel dependen dan tiga variabel independen. Variabel dependen dalam penelitian ini adalah pengungkapan tanggung jawab sosial, sedangkan variabel independenya adalah size perusahaan, profitabilitas, dan leverage.

\section{Variabel Dependen; Pengungkapan Tanggung Jawab Sosial}

Perhitungan indeks pengungkapan ini konsisten dengan penelitian sebelumnya yang dilakukan di Indonesia (Sembiring, 2003), yang dapat dinotasikan dalam rumus sebagai berikut:

$$
\operatorname{CSDI}=\frac{v}{79}
$$

Dimana:

CSDI = Indeks Pengungkapan Tanggung Jawab Sosial Perusahaan

$\mathrm{V}=$ Jumlah Item yang diungkapkan perusahaan

\section{Variabel Independen}

\section{Ukuran Perusahaan}

Ukuranperusahaan didasarkan pada jumlah aktiva (aktiva tetap, tidak berwujud dan lain-lain), jumlah tenaga kerja, volume penjualan dan kapitalisasi pasar (Cahyonowati, 2003). 
Pada penelitian ini ukuran perusahaan dinyatakan dengan jumlah aktiva pada industri pertambangan yang sudah terdaftar di BEI.

$$
\text { Size }=\sum \text { Asset }
$$

\section{Profitabilitas}

Profitabilitas diartikan sebagai kemampuan perusahaan untuk menghasilkan laba atau profit dalam upaya meningkatkan nilai pemegang saham. Ukuran untuk menentukan profitabilitas perusahaan, yaitu : return of equity, return on assets, earning per share, net profit dan operating ratio.

$$
\text { ReturnOnAsset }=\frac{\text { EarningBeforeInterestandTax }}{\text { TotalAsset }}
$$

\section{Leverage}

Dalam penelitian ini, indikator yang digunakan untuk mengukur tingkat leverage adalah Debt To Equity Ratio (DER). Adapun pengukuran dalam penelitian ini dengan menggunakan rumus:

$$
\text { DebttoEquityRatio }(\text { DER })=\frac{\text { TotalHutang }}{\text { TotalEkuitas }}
$$

\subsection{Teknik Analisis Data}

Sebelum dilakukan analisa data, terlebih dahulu dilakukan uji asumsi klasik, dan dalam menganalisa data digunakan model persamaan regresi linear berganda, sebagai berikut:

$$
\begin{aligned}
& \mathbf{Y}=\mathbf{a}+\mathbf{b} 1 \mathbf{X} 1+\mathbf{b} \mathbf{2} \mathbf{2}+\mathbf{b} \mathbf{3 X} \mathbf{3}+\boldsymbol{e t} \\
& \text { Keterangan: } \\
& \mathrm{Y}=\text { Pengungkapan Tanggung Jawab Sosial } \\
& \mathrm{a}=\text { Konstanta } \\
& \text { b1, b2, b3, b4 = Koefisien regresi } \\
& \mathrm{X} 1=\text { Ukuran Perusahaan } \\
& \mathrm{X} 2=\text { Profitabilitas } \\
& \mathrm{X} 3=\text { Leverage } \\
& \text { et }=\text { error term }
\end{aligned}
$$




\section{Hasil dan Pembahasan}

\subsection{Hasil Pengolahan Data}

Deskripsi Statistik Variabel Penelitian

Tabel1

Statistik Deskriptif

\begin{tabular}{|c|c|c|c|c|c|}
\hline & $\mathbf{N}$ & Minimum & Maximum & Mean & Std. Deviation \\
\hline Size & 64 & 23.05 & 31.96 & 29.1538 & 1.98771 \\
\hline $\begin{array}{l}\text { Profitabilitas } \\
(\mathrm{ROA})\end{array}$ & 64 & -74.00 & 47.00 & 7.2404 & 15.49873 \\
\hline $\begin{array}{l}\text { Leverage } \\
(\mathrm{DER})\end{array}$ & 64 & -292.90 & 947.10 & 109.2467 & 155.61004 \\
\hline CSR & 64 & .41 & .63 & .5351 & .05891 \\
\hline $\begin{array}{ll}\text { Valid } & \mathrm{N} \\
\text { (listwise) } & \end{array}$ & 64 & & & & \\
\hline
\end{tabular}

Sumber: Data Sekunder Diolah, 2013

Statistik deskriptif menunjukan nilai minimum, nilai maksimum, mean, dan standar deviasi masing - masing variabel. Berdasarkan Tabel1 dapat diketahui bahwa variabel CSR memiliki nilai minimum 0,41 , nilai maksimum 0,63 , mean 0,5351 , dan standar deviasi 0,05891. Variabel Size memiliki nilai minimum 23,05 yaitu PT. Golden Eagle Energy, Tbk pada tahun 2010, nilai makismum 31,96 yaitu PT. Bumi Resources, Tbk pada tahun 2009, mean 29,1538 dan standar deviasi 1,98771. Data total aset dari sampel perusahaan memiliki variasi yang sangat besar, maka data ukuran perusahaan dan sebagaimana pada penelitian terdahulu, selanjutnya variabel ukuran perusahaan disajikan dalam bentuk transformasi logaritma natural dari total aset. Variabel profitabilitas memiliki nilai minimum -74,00 yaitu PT. Golden Eagle Energy, Tbk, nilai maksimum 47,00 yaitu PT. Resource Alam Indonesia, Tbk pada tahun 2011, mean 7,2404, dan standar deviasi 15,49873. Variabel leverage memiliki nilai minimum -292,90 yaitu PT. Golden Eagle Energy, Tbk pada tahun 2009, nilai maksimum 947,10 yaitu PT. Bumi Resources, Tbk pada tahun 2012, mean 109,2467 dan standar deviasi 155,61004 . 


\section{Analisis Data}

Pada tahap awal, data yang meliputi Size, Profitabilitas, Leverage dan CSR diperoleh dengan mengutip secara langsung Laporan Tahunan pada Bursa Efek Indonesia selama periode tahun 2009 - 2012.

\section{Uji Normalitas}

Uji normalitas data pada Perusahaan Pertambangan dapat dilihat pada Gambar 2 di bawah ini:

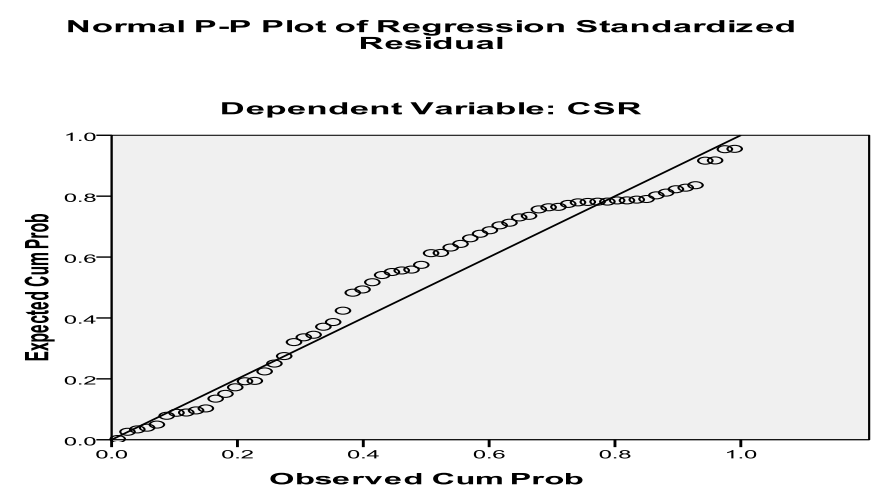

Dengan melihat tampilan grafik Normal P-Plot dapat disimpulkan bahwa pola distribusi data mendekati normal. Hal tersebut terlihat dari sebaran titik-titik pada grafik mendekati garis diagonal.

\section{Uji Multikolinearitas}

Suatu model regresi pada perusahaan perbankan dinyatakan bebas dari multikolinearitas jika mempunyai nilai Tolerence dibawah 1 dan nilai VIF di bawah 10. Dari hasil analisa diketahui bahwa variabel ukuran perusahaan memiliki Tolerance 0,802 dan VIF 1,246; variabel profitabilitas memiliki nilai Tolerance 0,890 dan VIF 1,123; variabel Leverage memiliki nilai Tolerance 0,824 dan VIF 1,214;. Jadi, dapat disimpulkan bahwa variabel Ukuran Perusahaan, Profitabilitas, dan Leverage tidak terjadi multikolinearitas.

\section{Uji Autokorelasi}

Pengujian autokorelasi pada penelitian ini menggunakan statistik uji Durbin Watson. Berdasarkan analisa yang dilakukan, maka diperoleh nilai Durbin Watson sebesar 2,273. Pada Perusahaan pertambangan besarnya DW-tabel : dl (batas bawah) =1,4990; du (batas atas) $=1,6946 ; 4-\mathrm{du}=2,3054 ;$ dan 4-dl = 2,5010. Dengan demikian, Durbin Watson berada 
antara du dan 4-du, yaitu $1,6946<2,273<2,3054$. Jadi dapat disimpulkan bahwa tidak terjadi autokorelasi.

\section{Uji Heterokedatisitas}

Berdasarkan hasil uji heteroskedastisitas menggunakan uji Glejser diperoleh hasil nilai Sig > 0,05. Karena nilai Sig > 0,05 maka dapat dikatakan bahwa tidak terdapat heteroskedastisitas.

\subsection{Pengujian Hipotesis}

\section{Analisis Regresi Berganda}

Berdasarkan hasil penelitian, untuk analisis linier berganda dilihat pada tabel 4.10 penelitian ini adalah sebagai berikut:

Tabel. 2

Hasil Regresi Linear Berganda

\begin{tabular}{|l|l|l|l|l|l|l|}
\hline \multicolumn{2}{|c|}{} & \multicolumn{2}{|l|}{$\begin{array}{l}\text { Unstandardized } \\
\text { Coefficients }\end{array}$} & $\begin{array}{l}\text { Standardized } \\
\text { Coefficients }\end{array}$ & & \\
\cline { 2 - 5 } \multicolumn{2}{|l|}{ Model } & $\mathrm{B}$ & $\begin{array}{l}\text { Std. } \\
\text { Error }\end{array}$ & Beta & $\mathrm{T}$ & Sig. \\
\hline 1 & (Constant) & .066 & .094 & & .701 & .486 \\
& LNSize & .016 & .003 & .546 & 4.906 & .000 \\
& Profitabilitas & .001 & .000 & .249 & 2.353 & .022 \\
& Leverage & $-0,00008635$ & .000 & -.228 & -2.076 & .042 \\
\hline \multicolumn{2}{|l|}{ a. Dependent Variable: CSR } \\
\hline
\end{tabular}

Sumber: Data Sekunder Diolah, 2013

Dari hasil tabel 2 diatas, maka persamaan regresi yang dihasilkan adalah sebagai berikut:

$\mathrm{CSR}=0,066+0,16$ Size + 0,001 Profitabilitas $-0,00008635$ Leverage + error term

Dari persamaan regresi yang ada, maka persamaan regresi tersebut dapat diartikan sebagai berikut:

1. Besarnya konstanta adalah 0,066. Hal ini menunjukkan bahwa jika semua variabel bebas tidak berpengaruh, maka besarnya Pengungkapan tanggung jawab sosial adalah 0,066 . 
2. Variabel Ukuran Perusahaan dengan nilai 0,016 bertanda positif yang artinya ukuran perusahaan mempunyai hubungan yang searah terhadap pengungkapan tanggung jawab sosial atau setiap kenaikan sebesar 1 satuan maka akan menyebabkan bertambahnya pengungkapan tanggung jawab sosial sebesar 1,6\% apabila faktor-faktor lainnya konstan.

3. Variabel Profitabilitas dengan nilai 0,001 bertanda positif yang artinya profitabilitas mempunyai hubungan yang searah terhadap pengungkapan tanggung jawab sosial atau setiap kenaikan sebesar 1 satuan maka akan menyebabkan bertambahnya pengungkapan tanggung jawab sosial sebesar $0,1 \%$ apabila faktor-faktor lainnya konstan.

4. Variabel Leverage dengan nilai $-0,00008635$ bertanda negatif yang artinya leverage mempunyai hubungan yang berlawanan terhadap pengungkapan tanggung jawab sosial atau setiap kenaikan sebesar 1 satuan maka akan menyebabkan berkurangnya pengungkapan tanggung jawab sosial sebesar 0,008635\% apabila faktor-faktor lainnya konstan.

\section{Uji Parsial (Uji T)}

Pengujian ini bertujuan untuk menguji pengaruh variabel bebas (Size, Profitabilitas, dan Leverage) berpengaruh signifikan ataukah tidak terhadap CSR pada sektor industri pertambangan yang terdaftar di Bursa Efek Indonesia periode 2009-2012 pada tingkat signifikansi $\alpha=5 \%$ secara terpisah atau parsial. Berdasarkan tabel 2 dapat disimpulkan sebagai berikut:

1. Hasil pengujian Variabel Size terhadap CSR

Hipotesis pertama yang diajukan menyatakan bahwa Size berpengaruh positif terhadap CSR. Berdasarkan hasil penelitian diperoleh t hitung untuk variabel Size sebesar 4,906 dengan tingkat signifikansi 0,000 yang menunjukkan berada di bawah 0,05, hal ini berarti variabel Sizeberpengaruh positif terhadap CSR pada industri pertambangan yang terdaftar di Bursa Efek Indonesia sehingga hipotesis pertama yang diajukan dalam penelitian ini diterima.

2. Hasil pengujian Variabel Profitabilitas terhadap CSR

Hipotesis kedua yang diajukan menyatakan bahwa profitabilitas berpengaruh positif terhadap CSR. Berdasarkan hasil penelitian diperoleh $\mathrm{t}$ hitung variabel untuk profitabilitas sebesar 2,353 dengan tingkat signifikansi 0,022 yang menunjukkan berada di bawah 0,05 , hal ini berarti variabel profitabilitas berpengaruh positif terhadap CSR 
pada industri pertambangan yang terdaftar di Bursa Efek Indonesia sehingga hipotesis kedua yang diajukan dalam penelitian ini diterima.

3. Hasil pengujian Variabel Leverage terhadap CSR

Hipotesis ketiga yang diajukan menyatakan bahwa leverage berpengaruh negatif terhadap CSR. Berdasarkan hasil penelitian diperoleh thitung untuk variabel leverage sebesar -2,076 dengan tingkat signifikansi 0,042 yang menunjukkan berada di bawah 0,05, hal ini berarti variable Leverageberpengaruh negatif terhadap CSR pada industri pertambangan yang terdaftar di Bursa Efek Indonesia sehingga hipotesis pertama yang diajukan dalam penelitian ini diterima.

\section{Uji Koefisien Determinasi}

Hasil perhitungan koefisien determinasi AdjustedR Square pada perusahaan pertambangan di Indonesia dapat dilihat pada Tabel 3 berikut:

Tabel 3

Hasil Perhitungan Koefisien Determinasi $\left(\mathbf{R}^{2}\right)$ Perusahaan Pertambangan Di BEI

\begin{tabular}{|c|c|c|c|}
\hline Model & $\mathrm{R}$ & R Square & $\begin{array}{|ll|}\text { Adjusted } & \mathrm{R} \\
\text { Square } & \\
\end{array}$ \\
\hline 1 & $.635^{\mathrm{a}}$ & .403 & .374 \\
\hline
\end{tabular}

Sumber: Data Sekunder Diolah, 2013

Berdasarkan output SPSS pada tabel 3. di atas tampak bahwa dari hasil perhitungan diperoleh nilai koefisien determinasi AdjustedR Square pada perusahaan pertambangan di Indonesia sebesar 0,374. Hal ini menunjukkan bahwa besar pengaruh variabel independen yaitu Size, Profitabilitas, dan Leverage terhadap variabel dependen CSR yang dapat diterangkan oleh model persamaan ini sebesar 37,4\% sedangkan sisanya sebesar $62,6 \%$ dipengaruhi oleh faktor-faktor lain diluar variabel penelitian. 


\section{Kesimpulan, Saran dan Keterbatasan Penelitian}

\subsection{Kesimpulan}

Berdasarkan hasil penelitian yang telah dijelaskan pada Bab IV, peneliti dapat mengambil kesimpulan sebagai berikut :

1. Secara partial ukuran perusahaan berpengaruh positif terhadap pengungkapan tanggung jawab sosial perusahaan.

2. Secara partial profitabilitas berpengaruh positif terhadap pengungkapan tanggung jawab sosial perusahaan.

3. Secara partial leverage berpengaruh negatif terhadap pengungkapan tanggung jawab sosial perusahaan.

\subsection{Saran}

Berdasarkan beberapa keterbatasan penelitian yang telah diungkapkan, maka diberikan saran untuk penelitian selanjutnya, yaitu:

1. Penelitian selanjutnya dapat menambah variabel independen yang terkait dengan pengungkapan CSR, seperti tipe industri, kepemilikan manajemen dan lain-lain.

2. Jumlah sampel ditambah sehingga dapat menambah kekuatan prediksi dari penelitian.

3. Penelitian selanjutnya perlu mempertimbangkan penggunaan media pelaporan yang lain yang digunakan untuk menentukan pengungkapan tanggung jawab sosial.

\subsection{Keterbatasan Penelitian}

Penelitian ini mempunyai keterbatasan diantaranya, yaitu:

1. Variabel-variabel yang bisa digunakan untuk mengetahui pengaruh terhadap CSR ada banyak, namun dalam penelitian ini hanya empat variabel yang digunakan yaitu, variabel independen: size, profitabilitas, dan leverage; serta satu variabel dependen, yaitu CSR. Sehingga untuk penelitian selanjutnya perlu adanya penambahan variabelvariabel independen yang lain agar mampu menjelaskan jumlah informasi sosial yang diungkapkan.

2. Sampel yang digunakan hanya perusahaan pertambangan, sehingga tidak diketahui bagaimana pengaruh variabel independen terhadap variable dependen pada jenis perusahaan lain, seperti jasa, perbankan, manufaktur dan lainnya. 
DAFTAR PUSTAKA

Anggraini, Fr.Reni Retno. 2006. "Pengungkapan Informasi Sosial dan Faktor-Faktor yang Mempengaruhi Pengungkapan Informasi Sosial dalam Laporan Keuangan Tahunan (Studi Empiris pada Perusahaan-Perusahaan yang terdaftar Bursa Efek Jakarta)”, Simposium Nasional Akuntansi IX, Padang.

Belkaoui, Ahmed and Philip G Karpik, 1989. Determinants of the Corporate Decision to Diclose Social Information. Accounting, Auditing and Accountability Journal. Vol.3 no.2.

Cahya, Bramantya Adhi. 2010. Analisis Pengaruh Kinerja Keuangan Terhadap Tanggung Jawab Sosial Perusahaan (Corporate social responsibility) (Studi Pada Bank Di Indonesia Periode Tahun 2007-2008). Skripsi, Fakultas Ekonomi, Universitas Diponegoro, Semarang.

Cahyonowati, Nur. 2003. Analisis Faktor-Faktor yang Mempengaruhi Pengungkapan Sosial (Social Disclosure) dalam Laporan Tahunan Perusahaan. Skripsi, Fakultas Ekonomi, Universitas Diponegoro, Semarang.

Darwin, Ali, 2004. Penerapan Sustainability Reporting di Indonesia. Konvensi Nasional Akuntansi V, Program Profesi Lanjuta., Yogyakarta.

Dowling, John and Jeffrey Pfeffer. 1975. Organizational Legitimacy, Social Values and Organizational Behavior. Pacific Sociological Review. 18.

Gray, R.H. et al. 1995. Timing of conception and the risk of spontaneous abortion among pregnancies occuring during the use of natural family planning. Am J Obstet Gynecol. 172: $1567-1572$.

Ghozali, Imam dan Chariri, Anis. 2007. Teori Akuntansi, Edisi 3, Universitas Diponegoro, Semarang.

2009. Aplikasi Analisis Multivariat dengan Program SPSS. Edisi

Keempat. Semarang : Badan Penerbit Universitas Diponegoro.

Harahap, Sofyan S. 2001. Menuju Perumusan Akuntansi Islam. Pustaka Quantum Jakarta. -2007. Analisa Kritis atas Laporan Keuangan, Jakarta : PT.Raja Grafindo Persada.

Hasibuan, Rizal. 2001. Pengaruh Karakteristik Perusahaan Terhadap Pengungkapan Sosial. Tesis, Universitas Diponegoro, Semarang. 
Lucyanda, J., \& Siagian, L. G.2012. The Influence of Company Characteristics Toward Corporate Social Responsibility Disclosure. The 2012 International Conference on Business and Management 6 - 7 September 2012, Phuket - Thailand.

Marbun, Daniel B. 2008. Analisis Faktor-Faktor yang Mempengaruhi Pengungkapan Tanggungjawab Sosial, tudi Empiris pada Perusahaan yang Terdaftar di Bursa Efek Indonesia. Skripsi,Universitas Riau, Pekanbaru.

Memed, Sueb. 2001. Pengaruh Akuntansi Sosial terhadap Kinerja Sosial dan Keuangan Perusahaan Terbuka di Indonesia. Disertasi. Universitas Padjadjaran, Bandung. Tidak Dipublikasikan.

Mirza, Teuku \& Imbuh S. 1997. Konsep Economic Value Added, Pendekatan untuk Menentukan Nilai Riil Perusahaan dan Kinerja Riil Manajemen, Usahawan No. 01 Th XXVIII.

Pian, Angling Mahatma. 2010. Pengaruh Karakteristik Perusahaan dan Regulasi Pemerintah Terhadap Pengungkapan Corporate Social Responsibility (CSR). Fakultas Ekonomi Universitas Diponegoro: Semarang.

Raharjaputra, Hendra S. 2009. Manajemen Keuangan dan Akuntansi, Salemba 4, Jakarta.

Rawi dan Munawar Muchlish. 2010. Kepemilikan Manajemen, Kepemilikan Institusi, Leverage dan Corporate Social Responsibility. Makalah disampaikan pada Simposium Nasional Akuntansi XII. Puwokerto.

Rosmasita, Hardhina. 2007. Faktor-faktor yang mempengaruhi Pengungkapan Sosial (Social Disclosure) dalam laporan keuangan tahunan perusahaan manufaktur di Bursa Efek Jakarta. Skripsi, Program studi Akuntansi. Universitas Islam Indonesia.

Sembiring, Eddy Rismanda. 2003. Pengaruh karakteristik Perusahaan Terhadap Pengungkapan Tanggungjawab sosial: Study Empiris Pad perusahaan Yang Tercatat (Go - Public) di Bursa Efek Jakarta. Tesis, Program Studi Magister Sains Akutansi Program Pascasarjana. Universitas Diponegoro. Semarang.

Sembiring, Eddy Rismanda. 2005. Karakteristik Perusahaan dan Pengungkapan Tanggung Jawab Sosial: Studi Empiris pada Perusahaan yang Tercatat di Bursa Efek Jakarta. Simposium Nasional Akuntansi 8. Solo.

Sitepu, Andre Christian, dan Siregar, Hasan Sakti. 2007. Faktor-faktor Yang Mempengaruhi Pengungkapan Informasi Sosial Dalam Laporan Tahunan Pada Perusahaan Manufaktur Yang Terdaftar Di BEJ. Jurnal Akuntansi Vol. 19.

Sutrisno. 2003. Manajemen Keuangan. Edisi Pertama. Ekonisia. Yogyakarta. 
Undang-Undang Republik Indonesia No. 40 Tahun 2007 tentang “Perseroan Terbatas".

Weston, Fred, J,. dan Brigham, F. Eugene. 1990. Manajemen Keuangan, Edisi Ketujuh, Jilid Dua, Erlangga. Jakarta, hal 150-154.

Zuhroh, D. dan Sukmawati. 2003. Analisis pengaruh luas pengungkapan sosial dalam laporan tahunan perusahaan terhadap reaksi investor (studi kasus pada perusahaan-perusahaan high profile di BEJ). Simposium Nasional Akuntansi VI (SNA VI), 1314-1341.

www.globalreporting.org

$\underline{\text { www.idx.co.id }}$ 